\title{
Optimization the Role of Shariah Supervisory Board for Shariah Governance in Islamic Banking
}

\author{
Izzani Ulfi ${ }^{1 *}$, Ujang Syahrul Mubarrok ${ }^{2}$, Muhamad Wahyudi $^{3}$ \\ ${ }^{1}$ Gunadarma University, Indonesia, ${ }^{2}$ Islamic University of Kadiri, Indonesia, ${ }^{3}$ Tidar University, Indonesia
}

Many studies show that one of the biggest challenges in Islamic banking is related to lack of proper and effective Shariah governance. By focusing on the role of Shariah Supervisory Board (SSB), this paper attempts to extract some keys on how to achieve better performance and development of Islamic banking industry by reviewing previous studies. This study was done by using literature review approach. This study concludes that increasing the size of SSB, improving higher skills and competences of SSB members, keeping the independency of SSB member as well as the need of Central Shariah Board (CSB) and shariah auditor would affect to better performance of Islamic banking.

Keywords: : Islamic Banks, Supervisory Shariah Board, Shariah Governance, Good Governance

OPEN ACCESS

ISSN 2503-3077 (Online) (online)

ISSN 2503-3077 (print)

${ }^{*}$ Correspondence:

Izzani Ulfi

Izzani@staff.gunadarma.ac.id

Received: 21 February 2020

Accepted: 21 March 2020

Published: 21 April 2020

Citation:

Ulfi I, Mubarrok US and Wahyudi M (2020) Optimization the Role of Shariah Supervisory Board for Shariah Governance in Islamic

Banking.

Perisai : Islamic Banking and

Finance Journal. 4:1.

doi: 10.21070/perisai.v4i1.515 


\section{INTRODUCTION}

Islamic bank is financial institution that operated under Islamic law. Islamic bank is not only following Islamic law (shariah) but also holds Islamic value and paradigm. The main point that distinguishes Islamic bank from conventional one that well known by society is riba free which is in conventional bank appears in the form of interest. Riba is an Arabic noun also known as ziyadah, meaning 'to increase', 'to grow', and 'to exceed. Interest in the conventional bank is a form of riba because it is present due to additional value that stated in the contract or become pre-requirement when bank distributes loans such as car loans, home loans or credit card debt to customer. That additional condition is prohibited in Islam.

In the case of governance, the existence of the Shariah Supervisory Board (SSB) in Islamic Bank is one of the features that distinguish the Conventional Bank and Islamic Bank system. The SSB is needed to ensure the shariah compliance of product implementations and any activities related to Islamic financial institution which in this case is Islamic bank. AAOFI has come up with a set of legal frameworks to ascertain that the product and operations of Islamic Financial Institution (IFI) comply with Shariah principles.

Shariah board members, as a person or a group who are assigned to cater this ascertainment, have been associated with duties and responsibilities. The duties and responsibilities of SSB encompass these main aspects such as supervise the shariah compliance on bank transactions, to supervise and approve the development of shariah-compliant investment and financing product as well as to certify shariah compliance of bank's product documents, contracts, and agreements.

Unfortunately, many studies show that one of the biggest challenges in Islamic banking is related to a lack of proper and effective shariah governance (Abozaid, 2016). Various studies also show that the implementation of shariah compliance is a critical issue. Sepky (2015) says that the independence, multiserved position of Shariah Supervisory Board, competences and shariah audit are become three main points to evaluate the degree of shariah compliance in Islamic bank. However, it important to note that every country's typical structure, functions, duties, and responsibilities might be different (Grassa, 2013).

Another study from Grassa (2015) that compared shariah governance among OIC countries concluded that most of these shortages are linked to the current regulatory frameworks, the roles and the responsibilities of the national Shariah authority and the duties and attributes of the institutional Shariah Board. At the national level, the absence of or weak monitoring and control allows the development of new doubtful products or interest-based products under the ruse that they are Shariahcompliant products. Also, it can permit the diffusion and circulation of strange fatwas which, in turn, can threaten the credibility of Islamic which in the end would lead to the loss of trust in Islamic bank users.

This trust issue might lead to another problem such as mas- sive fund withdrawal by Islamic bank customers. Another possibility is there will be re-shifting from Islamic bank customers to the conventional bank as they feel like there are no significant differences between Islamic banks and conventional banks. As a result, sharia non-compliance in Islamic banks may lead to the loss of investment or reinvestment income (Hamza, 2013). If this happened, it becomes harder to expect higher growth from the Islamic banking industry.

Therefore, this paper attempts to examine the implementation of shariah governance in the Islamic banking industry focusing on the role of Shariah Supervisory Board (SSB). It is believed that better implementation of shariah governance through better performance of SSB potentially contributes to better performance and future development of Islamic banks. The method used in this paper is a literature study that contains summary, classification, and comparison of prior previous research studies.

\section{LITERATURE REVIEW}

The concept of corporate governance initially built for mitigating agency problems in a company. In 1976, Jensen \& Meckling developed agency theory which implies a separation between the director (management) and the owner (stockholder) of the firm management to avoid any conflict of interest. This theory is adapted in the firms until now including the banks' industry. In general, the purpose of corporate governance is to build transparency, accountability, fairness, and responsibility as those are the core principles of good corporate governance.

However, there are some differences in conventional corporate governance compared to the concept of Islamic corporate governance. For example, the core principles of corporate governance are held for company and shareholders while in the Islamic concept it is also held as the responsibility to Allah (Abu-Tapanjeh, 2009). There is also one crucial element that only Islamic corporate governance has, that is the existence of the Shariah Supervisory Board (SSB). According to the IFSB (2009), some SSB's primary duties are advising the Board of Directors on any shariah matters, reviewing shariah related policies and guidelines, and validating relevant documents for a new product of Islamic financial service.

There are many studies concern about SSB in Islamic Institution including Islamic Banking as well as Zakat and Waqf Institutions. This chapter attempts to review previous studies related to SSB issues and its proposed solution focusing on Islamic banking. F Farag et al. (2018) propose to increase the size of the SSB by appointing qualified scholars to mitigate agency relationships. A larger SSB, on the other hand, brings in the relevant resources to review the Shariah compliance of new Islamic financial instruments, for example, Islamic micro-finance due to the expansion of the Islamic finance business model worldwide. Therefore, Islamic banking regulators may encourage and support the establishment of professional institutions dedicated to training scholars to identify, under- 
stand and verify the authenticity of Shariah-compliant financial products, especially innovative instruments, and thereby to help ensure confidence in Islamic banks and their corporate governance. This result is also supported by (Almutairi and Qutainah, 2017), (Ajili and Bouri, 2018), (Mansour et al., 2016) (Nomran and Haron, 2020). They also add that the competences from shariah members are critical. Besides competency in Islamic law, SSB members with $\mathrm{PhD}$ in other specific skills such as accounting, finance and any other fields are needed.

Studies from Razak (2018), Alam et al. (2019) and Abdullah and Rahman (2017) proposing the centralization of the idea of a centralized approach to the corporate governance of Islamic financial institutions (IFIs) including Islamic bank. The roles of a Central Shariah Board (CSB) as the highest authority on Shariah issues and its distinguishing features from a decentralized system and the advantages and disadvantages of the two governance systems. The purpose of CSB is to supervise and control the SSB in Islamic Bank as well as prevent any problem in the future.

Haridan et al. (2018) find the compliance review process to be inadequately undertaken with SBs still excessively reliant on internal officers implying possible independence compromise. They highlight concerns relating to the general level of competency of individual Shariah Board members, lack of technical banking and finance knowledge, and Shariah Board members that generally fulfilling a ceremonial role rather than undertaking vigilant monitoring.

Noordin and Kassim (2019) stated that better composition of the Shariah Committee in terms of its size, academic background, and other relevant expertise would result in an effective monitoring system leading to better practices of Shariah disclosure and hold important role to improve voluntary Shariah disclosure level of the Islamic banks. They also suggested that Islamic banks need to give priority in providing more education and training in various areas of expertise to their Shariah Committee members which believed would result in greater confidence of investors, stakeholders, and the society on the information disclosed by the banks.

While doing their role, the SSB members need to be independent (Hamza, 2013), (Ahmad and Al-Aidaros, 2015). They cannot be appointed and have a double position in either management or board director. The SSB members also need to avoid double position as CSB members or shariah auditor. The independency of SSB would make them focus on their mission in supervision and keeping the consistency of shariah ruling which later can contribute to an efficient Shariah governance structure (Alam et al., 2019), (Ramly and Nordin, 2018). This also incorporates with the IFSB's guideline.

After reviewing some relevant journals, it is found that there are affiliations between shariah governance and Islamic bank performance. That means, better performance of SSB leads to higher performance of Islamic Banking. What can be concluded is better Islamic bank performance and development can be achieved through the role of Shariah Supervisory
Board (SSB). To summarize, there are four solutions proposed by previous studies. Those solutions are compiled from the articles that have been reviewed as follows: increasing the size of SSB, improve the skills and competency of SSB members, keeping the independency of SSB members as well as a need of Central Shariah Board and Sharia Auditor.

\section{DISCUSSION}

As previously said by F Farag et al. (2018) the larger size of SSB strengthened the review process of building financial instrument compliance. The bigger size of SSB is surely better than the smaller size of SSB. The duties and responsibilities of SSB that needs to be always available through pre-implementation, during implementation and post-implementation of operational in Islamic bank need huge support. Therefore, increasing the size of SSB is relevant to achieve better performance of Islamic banks. In Indonesia, according to Bank Indonesia Regulation number 11/ 3 /PBI/2009, the minimum shariah board member is two or a maximum $50 \%$ from total directors.

The minimum size of SSB should be based on how many backgrounds needed and incorporate to the Islamic bank business. For example, member expertise in ushul fiqh and fiqh muamalat, a member of expertise in Islamic finance and business, a member expertise in Islamic economic. That means a minimum number of SSB members is three which is higher than what Bank Indonesia Regulation has given. The various background would give broader insight in planning, implementing, and evaluating the operations of Islamic bank. Therefore, the SSB could contribute more and perform better.

The second one is improving the skills and competences of SSB members. As Islamic finance industry is a dynamic industry, the upgrade of SSB knowledge and skills are needed to be able keep up with new issues. It can be done by make an education background setting for SSB. For example, the educational background of SSB must be a Ph.D. holder or can be a master holder with minimum 5-year experiences. The education matters because higher education incorporates with higher job performance (NG and Feldman, 2009). While the skills can be improved along with working experiences.

The challenge of setting this requirement is the limited supply. That is why, in the earlier stage, the requirement cannot be strictly applied instead it needs to be gradually applied. Regarding this matter, educational institutions, especially higher education like university need to properly respond to this demand. A well-structured curriculum, soft-skill training, and character-building need to be facilitated and provided by higher education. With those qualities, it is expected that the graduates are able to cope up with the necessity of this industry.

The independency of SSB members is necessary to avoid the agency problem. The agency theory emphasizes on the separation between principal and agent because it can create asymmetric information and accommodate personal interest which can form moral hazard. Therefore, the SSB members must 
avoid any form of a double agent. AAOIFI in (Khalid et al., 2018) has stated that SSB members should be independent and should not become involved in management decisions, senior executive officer, or have a substantial shareholding in the IFI.

In the case of Indonesia, it is common for the SSB members involved in management. An SSB received an incentive from the entity which has an administrative relationship in management (Umam, 2015). A member of the National Sharia Board (DSN), Central Sharia Board in Indonesia, is allowed to serve in Islamic financial institutions and in charge of more than one Islamic bank. Indonesia Financial Services Authority (OJK) allows a shariah board to be in charge of up to four institutions. The similar applied in Bahrain and Kuwait. Meanwhile, Malaysia and Pakistan only allow a sharia advisor to serve in only one Islamic financial institution. From the table, it is concluded that Malaysia is the strictest and ideal one in terms of the independency of sharia advisors.

[Table 1 about here.]

\section{Source: various sources}

Indonesia, therefore, could adapt Malaysia regulation. In this case the policy is proposed to be revised. An SSB member need to be independence, free from another possible role and only focus on no more than one institution. There also needs a separation from National Sharia Board member and Sharia Advisor in IFI. A member of National Sharia Board cannot serve in IFI. While the policy is expected to be revised, the supply creation of professional shariah board and sharia advisor need to be adequate.

The next one is the need of control from Central Shariah Board (CSB). Although decentralization system grants the Islamic Financial Institution to have the autonomy to choose fatwas that suitable for both their legal environment and business interests, it is arguable that such freedom can lead to uncertainty and confusion among stakeholders such as investors and customers. Therefore, Islamic bank needs CSB. From table 3.1, four out of five countries have Central Shariah Board.

In Indonesia, National Shariah Board (DSN) is the form of CSB that provide fatwa, regulate and supervise of products and services in Islamic Financial Institution. A bit difference from another country that has Central Shariah Board under their Central Bank. National Shariah Board in Indonesia is established by Indonesian Ulema Council (MUI). It is built to cater the aspirations of Muslims regarding economic and financial problems, which includes Islamic Financial Institution, in accordance with the guidelines of Islamic law.

As human is inseparable from mistakes, the role of shariah auditor is critical. The shariah auditor is different from SSB. SSB acts as an internal controller while shariah auditor is the external controller. The responsibility of shariah auditors is to evaluate, whether the activities of the bank are being performed as per the guidelines issued, from time to time by SSB of the bank. By doing so, Islamic bank can always keep their operations on the right path and any problems appear can be anticipated. It is also can keep the peace of mind of the customer that trust Islamic bank. In the end, it can bring the loyalty of the customer to Islamic banking.

All in all, as the SSB members carry huge responsibilities, professional indemnity protection for SSB is needed. While this practice is common for a profession such as healthcare practitioners and business consultants, the application of this protection to SSB members is relevant. The purpose of professional indemnity for SSB members is to protect them from any legal matters that might appear while they conduct their ikhtiyar (effort) on giving shariah advice. This will bring the ease for SSB members in carrying out their responsibilities.

\section{CONCLUSION}

As a relatively new industry compared to conventional bank, Islamic bank is in need to always straighten up in term of their operational and performances. There are many issues related to Islamic banks. However, this paper points out the issues in shariah governance, specifically in the role of Shariah Supervisory Board on the development of Islamic banks. As a result of reviewing some articles related to the Shariah Supervisory Board in Islamic banks, this paper found that there are some solutions to overcome the issues and further development of the Islamic banking industry through shariah governance.

In the case of Indonesia, the National Shariah Board as Central Shariah Board is existing. Therefore, there is three more homework to be done. First, increasing the minimum size of SSB members in an Islamic bank. Setting standard background and experience of the SSB members as higher education incorporate to higher performance. This also needs to be supported by a well-structured curriculum, soft-skill training and character-building need to be facilitated and provided by the higher education to create competence graduates. Strengthened regulation on the independency of SSB members and the shariah auditor existence as an external control for Islamic banking also critical.

The result of this paper could be support material for the authority in Islamic financial institutions to evaluate and improve on what should be done to increase the shariah governance performance in the Islamic bank industry. By doing so, the growth if the Islamic banking industry, especially in Indonesia hopefully could be increase. Further study related to the regulation and the possibility of implementing the key solutions proposed in this paper is required.

\section{ACKNOWLEDGEMENT}

We thank Dr. Achsania Hendratmi from Faculty of Economic and Business, Universitas Airlangga, for giving her advice and support to finish this project. This work is done through selffunding support. There are no conflicts of interest to disclose. 


\section{REFERENCES}

Abdullah, M. F. and Rahman, A. A. (2017). Shariah governance of Islamic Banks in Bangladesh issues and challenges. Journal of Islamic Economics 13, 82-94.

Abozaid, A. (2016). The internal challenges facing Islamic finance industry. International Journal of Islamic and Middle Eastern Finance and Management 9, 222235. doi: 10.1108/imefm-05-2015-0056.

Abu-Tapanjeh, A. M. (2009). Corporate governance from the Islamic perspective: A comparative analysis with OECD principles. Critical Perspectives on Accounting 20, 556-567. doi: 10.1016/j.cpa.2007.12.004.

Ahmad, M. R. and Al-Aidaros, A. H. (2015). The Need of Independent Shariah Members in Islamic Cooperative Banks: An Empirical Study of Professional Accountants in Malaysia. International Review of Management and Business Research 4, 110-120.

Ajili, H. and Bouri, A. (2018). Corporate governance quality of Islamic banks: measurement and effect on financial performance. International Journal of Islamic and Middle Eastern Finance and Management 11, 470-487. doi: 10.1108/imefm05-2017-0131.

Alam, M. K., Rahman, S. A., Mustafa, H., Shah, S. M., and Hossain, M. S. (2019). Shariah Governance Framework of Islamic Banks in Bangladesh: Practices, Problems and Recommendations. Asian Economic and Financial Review 9, 118132. doi: 10.18488/journal.aefr.2019.91.118.132.

Almutairi, A. R. and Qutainah, M. A. (2017). Corporate Governance : Evidence from Islamic Banks. Social Responsibility Journal.

Farag, H., Mallin, C., and Ow-Yong, K. (2018). Corporate governance in Islamic banks: New insights for dual board structure and agency relationships. Journal of International Financial Markets, Institutions and Money 54, 59-77. doi: 10.1016/j.intfin.2017.08.002

Grassa, R. (2013). Shariah supervisory system in Islamic financial institutions: New issues and challenges: a comparative analysis between Southeast Asia models and GCC models. Humanomics 29, 333-348.

Grassa, R. (2015). Shariah supervisory systems in Islamic finance institutions across the OIC member countries. Journal of Financial Regulation and Compliance 23, 135-160. doi: 10.1108/jfrc-02-2014-0011.

Hamza, H. (2013). Sharia governance in Islamic banks: effectiveness and supervision model. International Journal of Islamic and Middle Eastern Finance and Management 6, 226-237.

Haridan, N. M., Hassan, A. F. S., and Karbhari, Y. (2018). Governance, religious assurance and Islamic banks: Do Shariah boards effectively serve? Journal of
Management and Governance 22, 1015-1043. doi: 10.1007/s10997-018-9418-8.

Khalid, A. A., Haron, H., Sarea, A. M., and Masron, T. A. (2018). The role of shariah supervisory board on internal Shariah audit effectiveness: Evidence from Bahrain. Academy of Accounting and Financial Studies Journal 22, 1-15.

Mansour, N., Thamar, N., and Hassan, R. (2016). Shariah Supervisory Board Characteristics Effects On Islamic Banks' Performance : Evidence from Malaysia. International Journal of Bank Marketing.

NG, T. W. H. and Feldman, D. C. (2009). HOW BROADLY DOES EDUCATION CONTRIBUTE TO JOB PERFORMANCE? Personnel Psychology 62, 89-134. doi: $10.1111 /$ j.1744-6570.2008.01130.x.

Nomran, N. M. and Haron, R. (2020). Shariah supervisory board's size impact on performance in the Islamic banking industry. Journal of Islamic Accounting and Business Research 11, 110-129. doi: 10.1108/jiabr-05-2017-0070.

Noordin, N. H. and Kassim, S. (2019). Does Shariah committee composition influence Shariah governance disclosure? Journal of Islamic Accounting and Business Research 10, 158-184. doi: 10.1108/jiabr-04-2016-0047.

Ramly, Z. and Nordin, N. (2018). Sharia Supervision Board, Board Independence, Risk Committee and Risk-taking of Islamic Banks in Malaysia. International Journal of Economics and Financial Issues 8, 290-300.

Razak, A. H. A. (2018). Centralisation of corporate governance framework for Islamic financial institutions. ISRA International Journal of Islamic Finance 10, 36-51. doi: 10.1108/ijif-08-2017-0020.

Sepky, M. (2015). Tingkat Kepatuhan Syariah di Lembaga Keuangan Syariah. Jurnal Akuntansi Dan Keuangan Islam 3, 57-68.

Umam, C. (2015). DEVELOPING INSTRUCTIONAL MATERIALS OF ENGLISH MORPHOLOGY FOR ENGLISH DEPARTMENT COLLEGE-LEARNERS. doi: 10.23971/jefl.v5i1.94. https://dx.doi.org/10.23971/jefl.v5i1.94.

Conflict of Interest Statement: The authors declare that the research was conducted in the absence of any commercial or financial relationships that could be construed as a potential conflict of interest.

Copyright () 2020 Ulfi, Mubarrok and Wahyudi. This is an open-access article distributed under the terms of the Creative Commons Attribution License (CC BY). The use, distribution or reproduction in other forums is permitted, provided the original author(s) and the copyright owner(s) are credited and that the original publication in this journal is cited, in accordance with accepted academic practice. No use, distribution or reproduction is permitted which does not comply with these terms. 


\section{LIST OF TABLES}

1 Sharia Governance in Some Islamic Countries 
TABLE 1 | Sharia Governance in Some Islamic Countries

Country Central Bank Sharia Board

Indonesia National Sharia Board, allowed to serve in IFI

Malaysia Sharia Advisory Council, not allowed to serve in IFI

Pakistan Sharia Advisory Council, allowed to serve in IFI

Kuwait

None

Bahrain

\section{Sharia Advisor}

Up to four institution

Only one IFI

Only one IFI

No limitation

No limitation 